\title{
A Review of the Pharmacological and Nutraceutical Properties of Cynodon dactylon
}

\author{
Shweta Das ${ }^{1}$, Sonia Morya ${ }^{2, *}$, Arno Neumann ${ }^{3}$, Vijay Kumar Chattu ${ }^{4}$
}

\section{Shweta Das ${ }^{1}$, Sonia Morya ${ }^{2, *}$, Arno Neumann ${ }^{3}$, Vijay Kumar Chattu ${ }^{4}$}

\section{'Department of Food Technology and Nutrition, Lovely Professional University, Phagwara, Jalandhar, Punjab, INDIA. 2Department of Food Technology and Nutrition, Lovely Professional University, Phagwara, Jalandhar, Punjab, INDIA. ${ }^{3} B E T$ Bioscience Extraction Technologies Inc., Abbotsford, B.C. CANADA. ${ }^{4}$ Department of Public Health Research, Global Institute of Public Health, Thiruvananthapuram, Kerala, INDIA. \\ Correspondence \\ Dr. Sonia Morya}

Assistant Professor, Department of Food Technology and Nutrition, School of Agriculture, Lovely Professional University, Phagwara, Punjab, INDIA.

Phone no: +91-9021398392

Email id: sonia.morya8911@gmail.com

History

- Submission Date: 15-01-2021.

- Review completed: 20-03-2021;

- Accepted Date: 01-05-2021

DOI : 10.5530/pres.13.3.1

Article Available online

http://www.phcogres.com

\section{Copyright}

(C) 2021 Phcog.Net. This is an openaccess article distributed under the terms of the Creative Commons Attribution 4.0 International license.

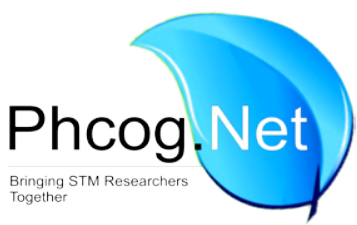

\begin{abstract}
Background: Cynodon dactylon is the scientific name of the common perennial grass whose lustre of green pasture covers the land. In layman's language, it is seen as a surface pasture in a sports field, garden lawns or terrace gardens, or as an unwanted weed in gardens. Many are unaware of its phytoconstituents, pharmacological and nutraceutical properties which progressively make science to aim for $C$. dactylon's enormous nutraceutical potential in curing problems like ulcers, diabetes, arrhythmia, diarrhoea, inflammation, edema and etc. Objectives: To discuss the constituents of phytochemicals and nutraceutical properties of $C$. dactylon with its curative investigation for various common ailments. Materials and Methods: Different kinds of extracts i.e. aqueous extract, ethanolic extract, alcoholic extract, hydro-alcoholic extracts etc. of $C$. dactylon were taken into account to study their curing potential against ailments organically. Results: Having its origin from east of Africa, it contains large amounts of biologically active compounds or phytochemical compounds, which has attracted many researchers to study its curative nutraceutical properties. Experiments conducted on animals have resulted in the effect of $C$. dactylon is, in the field of whether treating ailments or healing up excision or incision wounds, reducing ulcers, or improving the functioning of the muscular system and the circulatory system of the body. Conclusion: Biologically active phytocontituents in $C$. dactylon effective against the bodily ailments and are of high importance once the products are made easily available.
\end{abstract}

Key words: Cynodon dactylon, Nutraceutical, Pharmacological, Phytoconstituents, Extracts.

\section{INTRODUCTION}

Since a few decades, there has been a shift of interest by the researchers and scientists towards the medicinal properties embodied by plants. They have been useful in the long term without any side effects also helped in positive productivity in one's health lifestyle after being implemented. Diverse and various compounds which are biologically active and possess medicinal properties are obtained from plant origin. Anti-diabetic, anti-ulcer, anti-arrhythmic, anti-inflammatory and antioxidant are nutraceutical compounds extracted from plants. C. dactylon is one the plant which possesses nutraceutical properties abundantly. In the analysis of C. dactylon, phytochemicals like proteins, carbohydrates, terpenoids, flavonoids, alkaloids, saponins, glycosides, steroids, tannins and resins are seen to be present. It is also known as, Indian doob, durva grass, Bahama grass, Bermuda grass, wiregrass, villain's grass, dhoob, love seat grass, vilfastellata, grama, dubo, scutch grass, arugampul and canine's tooth grass. It aids inexpedient in bronchitis, leucoderma, widening of the spleen, bad breath, piles and asthma. It is suggested to use the curative property in the field of homeopathy to heal nearly all kinds of bleeding in addition to skin problems. ${ }^{[1]}$

Apart from the healing property it exhibits, it is traditionally used in worship chores in countries like India, Sri Lanka, Bangladesh, Bhutan and Nepal. The taxonomical classification $C$. dactylon is mentioned in Table 1.

C. dactylon was generally known to be in the east of Africa. It was then distributed extensively at above the sea level of 2000 meters of height or altitude. It is one kind of monocot weed that is inherent to Africa. Though it is not an inhabitant of Bermuda, it is a profuse obtrusive species there. It is set out to have landed in North America from Bermuda as pasture grass. It got transferred or distributed to the temperate and subtropical part of the world from east of Africa. It started to grow along the coastal region in the temperate parts and in the tropical areas where 650-1750 millimetres of rainfall was seen. It also grew along the riverside and the landscape regions irrigated in the arid zones of the Earth. It generally prefers warm weather with high light intensity. It can grow nearly anywhere in the world between about $30^{\circ} \mathrm{S}$ and $30^{\circ} \mathrm{N}$ scope and it can tolerate annual precipitation of 10 to $430 \mathrm{~cm}$. It is indeed a perennial, monocot warm weather grass that occurs on almost all kind of soil types. ${ }^{[4]}$ 
Table 1: Taxonomical classification of Cynodon dactylon.

\begin{tabular}{ccc}
\hline Kingdom & Plantae & References \\
\hline Sub kingdom & Tracheobionta & {$[2,3]$} \\
Super division & Spermatophyta & \\
Division & Magneliophyta & \\
Class & Liliosida & \\
Subclass & Commelinidae \\
Order & Cyperales \\
Family & Poaceae \\
Genus & Cynodon \\
Species & Cynodon dactylon \\
\hline
\end{tabular}

Table 2: Types of Cynodon dactylon.

\begin{tabular}{|c|c|c|c|}
\hline Type name & Type & Profile & References \\
\hline Midland & $\begin{array}{l}\text { Coastal + Winter } \\
\text { hardy }\end{array}$ & Tall, leafy & [8] \\
\hline Hardie & - & Sterile, $\mathrm{pH}<5$ & \\
\hline Guymon & $\begin{array}{l}\text { Established by } \\
\text { seeding }\end{array}$ & $\begin{array}{c}\text { Dense tillering, good winter } \\
\text { hardiness }\end{array}$ & \\
\hline Wrangler & Seeded Variety & $\begin{array}{c}\text { Good forage yield, average } \\
\text { winter hardiness }\end{array}$ & \\
\hline Greenfield & $\begin{array}{l}\text { Established by } \\
\text { sprigging }\end{array}$ & $\begin{array}{l}\text { Good cold tolerance, dense } \\
\text { sod, good stand capacity }\end{array}$ & \\
\hline Tifton 44 & $\begin{array}{c}\text { Coastal + winter } \\
\text { hardy }\end{array}$ & $\begin{array}{c}\text { Leafy, tall, better yield, good } \\
\text { stand }\end{array}$ & \\
\hline Midland 99 & Hay type & $\begin{array}{l}\text { Cold tolerant, average } \\
\text { forage quality }\end{array}$ & \\
\hline Quick stand & Winter hardy & $\begin{array}{l}\text { Used for turf, erosion } \\
\text { control, very dense sod }\end{array}$ & \\
\hline $\begin{array}{l}\text { World } \\
\text { feeder }\end{array}$ & $\begin{array}{l}\text { Moderate winter } \\
\text { hardy }\end{array}$ & Inferior forage yield & \\
\hline
\end{tabular}

Table 3: Phyto-constituents present in Cynodon dactylon.

\begin{tabular}{cccc}
\hline $\begin{array}{c}\text { Solvent/ } \\
\text { methods used } \\
\text { for extraction }\end{array}$ & $\begin{array}{c}\text { Phyto-constituents } \\
\text { obtained }\end{array}$ & $\begin{array}{c}\text { Amount } \\
\text { obtained }\end{array}$ & References \\
\hline $\begin{array}{c}\text { Gas } \\
\text { chromatography- } \\
\text { mass } \\
\text { spectrometry } \\
\text { (GC-MS) }\end{array}$ & Propane-1,2,3-triol & $38.49 \%$ & {$[36]$} \\
& Linoleoyl chloride & $15.61 \%$ & \\
Ethyl acetate & $9.50 \%$ & \\
Ethyl hexopyranoside & $8.42 \%$ & \\
Ethanol & Ethyl linoleate & $5.32 \%$ & \\
& Phytol & $4.89 \%$ & \\
Tyicosane & $22.05 \%$ & {$[26]$} \\
1, 2-propanediol & $20.30 \%$ & \\
3ydro-alcoholic & benzyloxy-1, 2 diacetyl & $12.62 \%$ & \\
& Dexadecanoic acid, & $17.49 \%$ & {$[26]$} \\
Dhenol & Linolenic acid & $11.48 \%$ & \\
& Hydroquinone & $69.49 \%$ & {$[9]$} \\
& Furfural & $6.0 \%$ & \\
& Levoglucosenone & $2.72 \%$ & \\
\hline
\end{tabular}

Development of $\mathrm{C}$. dactylon starts at temperatures around $15^{\circ} \mathrm{C}$ with ideal development somewhere between $24^{\circ} \mathrm{C}$ and $37^{\circ} \mathrm{C}$. In winter, due to a reduction in temperature and the intensity of light, the grass becomes lethargic and turns darker. Longer duration of bright sunshine hours exerts a positive influence on the growth of this kind of grass. On another contrary, development is hindered by shade, e.g., near large tree trunks. ${ }^{[5]}$ It is generally one foot tall. The grass has a high drought and alkali tolerance property andthe fast capability to heal from damage enduring elevated temperature, which explains its success as a turfgrass in sports grounds. ${ }^{[6]}$

The edges are sharp and unpleasant. It has dark green shading and is short. The erect stems can grow tall from 1-30 centimetres. ${ }^{[7]}$ The almost straightened stems are mostly tinged in purple shading. In a group of two to six spikes, seed heads are erected at the highest point of the stem, where each spike is $2-5$ centimetres in length. The root framework is profound and during parched spell circumstances with porous soil, it can develop to more than 2 metres (6.6 feet) profound. In most circumstances, the major part of the root mass is under 60 centimetres ( 24 inches) under the surface. The seed headings are in a cluster of spikes at the aerial part of the stem lengthening from 2-5 centimetres. Along the ground, the grass scuttles by its stolon and the roots if they contact any place on the ground, shapes into a thick tangle. Seeds, stolons and rhizhomes recreate C. dactylon ${ }^{[8]}$ Some varieties of $C$. dactylon with their prominent profile are enlisted in Table 2.

\section{Phytochemical properties of Cynodon dactylon}

Different morphological parts of $C$. dactylon, most evidently provided many recognized phytoconstituents. Minerals, carbohydrates, proteins, carotenoids, phenols, terpenoids, flavonoids, alkaloids etc. are some of the plant compounds. ${ }^{[9]}$ Quantification of other procured phytoconstituents is mentioned in Table 3.

Chemical structures of bioactive compounds present in C. dactylon are shown in the Figures (1-23).

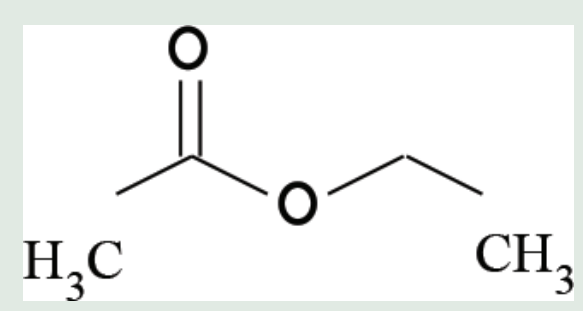

Figure 1: Ethyl acetate.

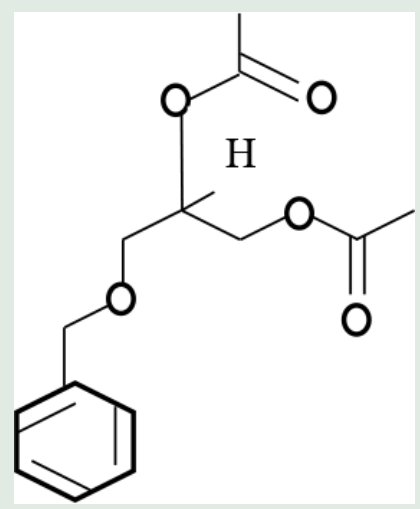

Figure 2: 3-benzyloxy-1, 2-diacetyl. 


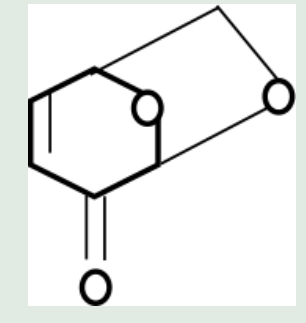

Figure 3: Levoglucosenone.

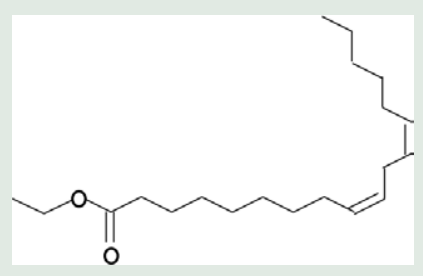

Figure 4: Ethyl linoleate.

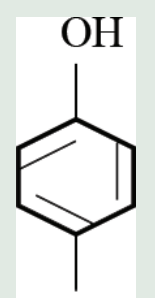

$\mathrm{HO}$

Figure 5: Hydroquinone.

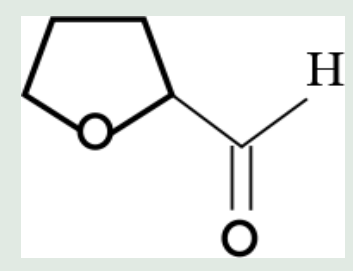

Figure 6: Furfural.

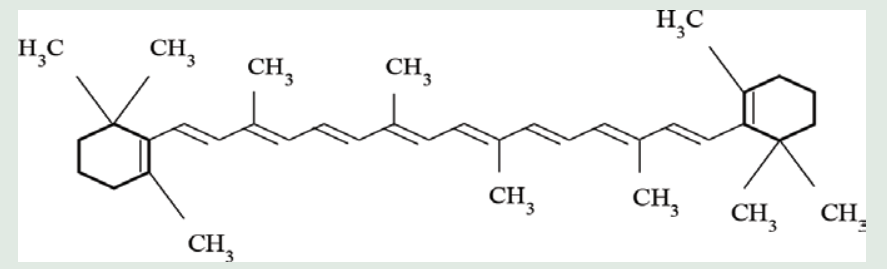

Figure 7: Betacarotene

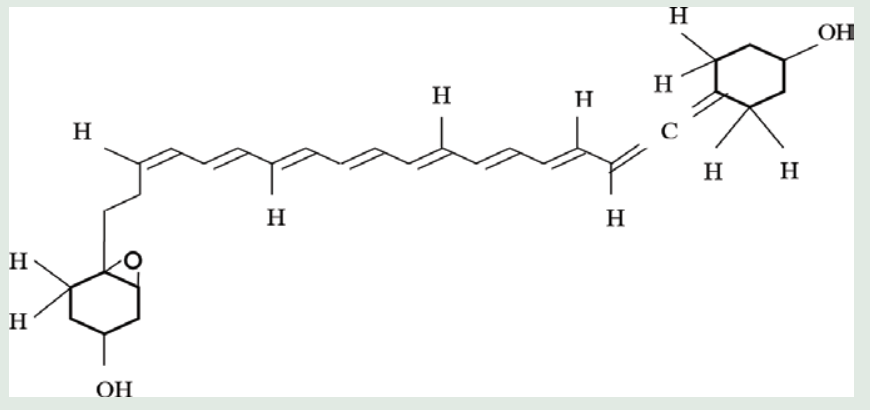

Figure 8: Neoxanthin.

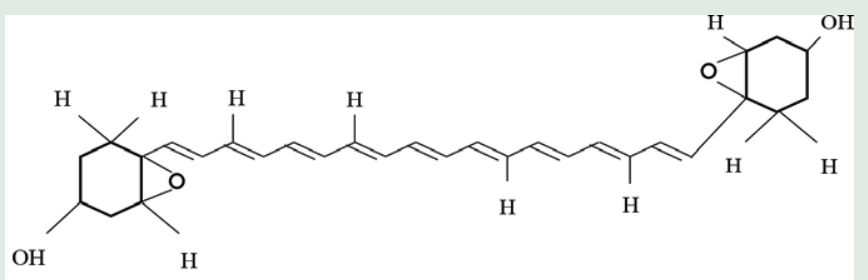

Figure 9: Violaxanthin.

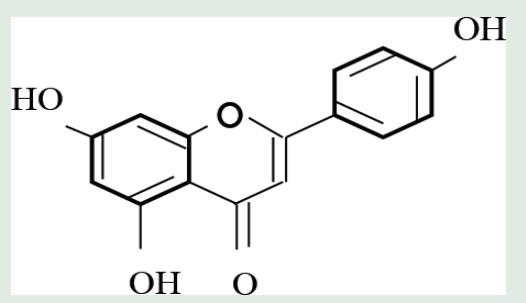

Figure 10: Apigenin.

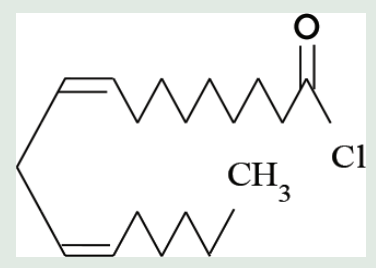

Figure 11: Linoleoyl chloride.

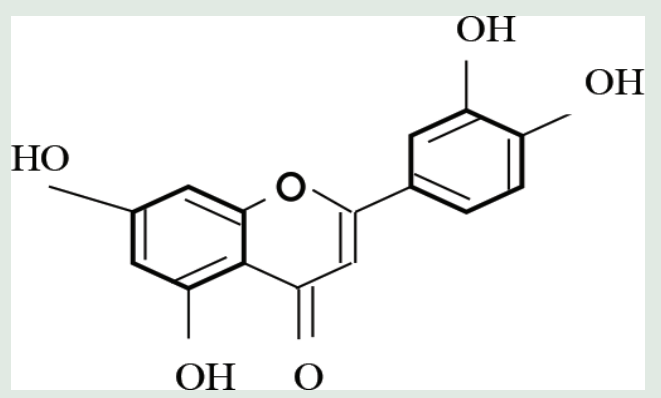

Figure 12: Luteolin. 


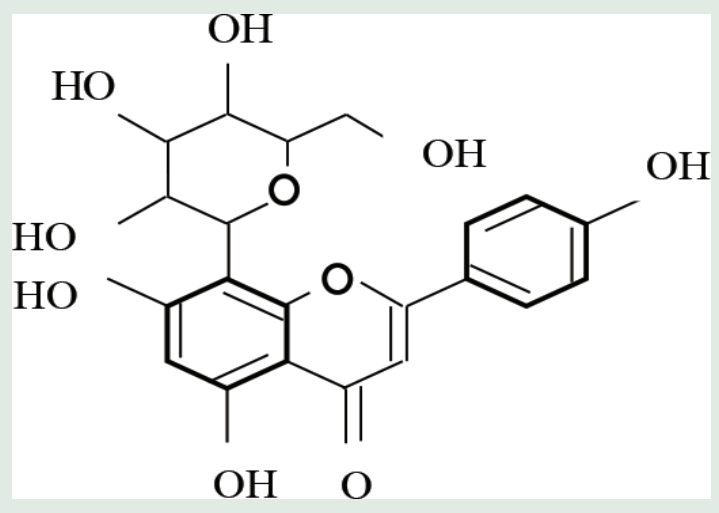

Figure 13: Vitexin.

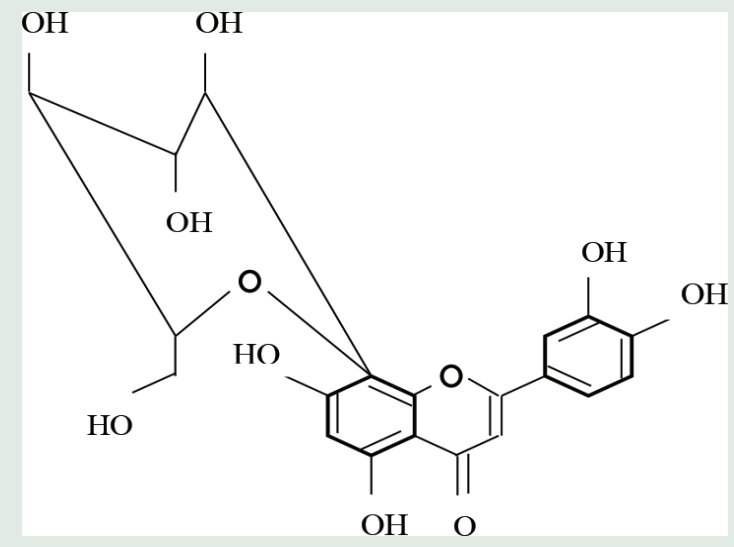

Figure 14: Orientin.

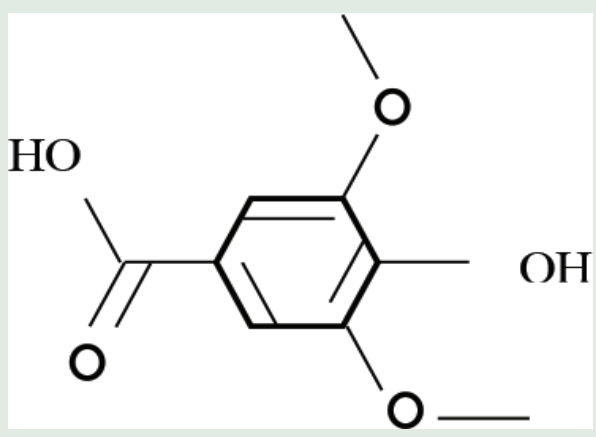

Figure 15: Syringic acid.

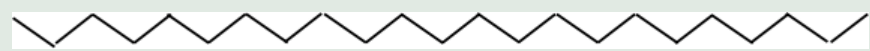

Figure 16: Tricosane.

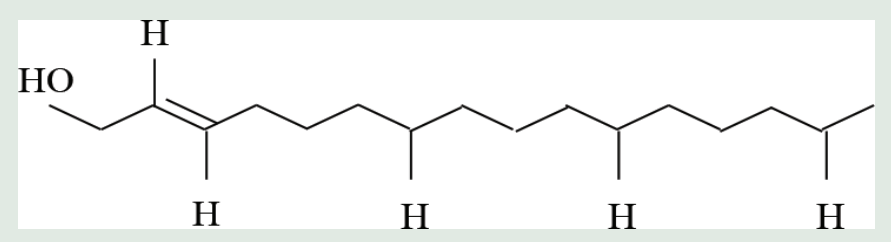

Figure 17: Phytol.

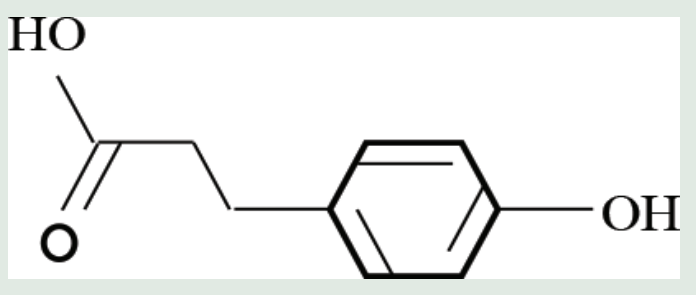

Figure 18: Paracoumaric acid.

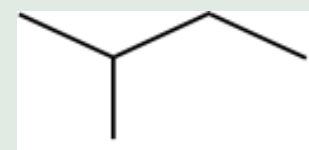

$\mathrm{OH}$

Figure 19: 1, 2-propanediol.

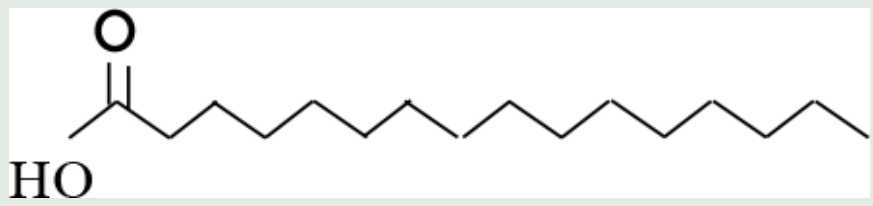

Figure 20: Hexadecanoic acid.

\section{$\mathrm{OH}$}

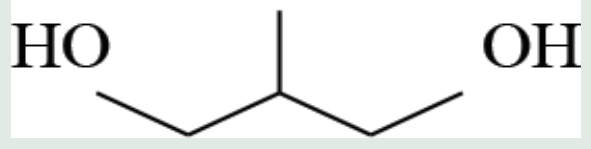

Figure 21: Propane-1, 2, 3-triol.

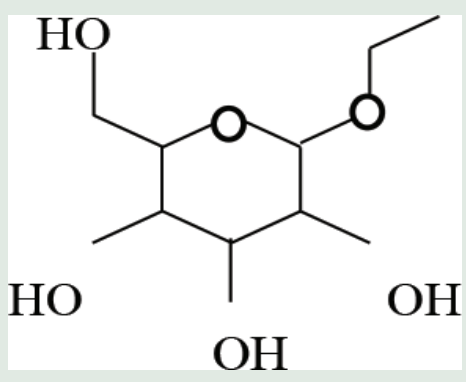

Figure 22: Ethyl hexopyranoside.

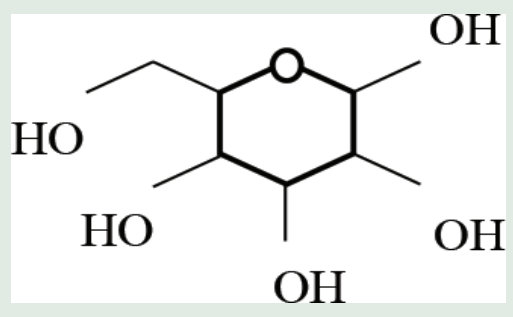

Figure 23: D mannose.. 
Table 4: Pharmacological action of Cynodon dactylon.

\begin{tabular}{|c|c|c|c|}
\hline Excerpts & Plant parts & Biological Action & References \\
\hline Aqueous & Entire plant & Anti-pyretic & {$[42]$} \\
\hline Aqueous & Entire plant & Analgesic & {$[42]$} \\
\hline Aqueous & Leaflets & Anti-microbial & {$[15]$} \\
\hline Methanolic & Rootstock & Anti-cancer & [36] \\
\hline Phenolic & Entire plant & Vasodilatory & {$[11]$} \\
\hline Aqueous & $\begin{array}{l}\text { Rhizomatous } \\
\text { stem }\end{array}$ & Anti-diuretic & [2912] \\
\hline $\begin{array}{l}\text { Aqueous and non- } \\
\text { polysaccharide fraction }\end{array}$ & Entire plant & Anti-diabetic & [10] \\
\hline Aqueous and ethanolic & Aerial parts & Anti-diabetic & {$[12]$} \\
\hline Ethanolic & Aerial parts & $\begin{array}{l}\text { Central nervous } \\
\text { system }\end{array}$ & {$[32]$} \\
\hline $\begin{array}{l}50 \% \text { aqueous- } \\
50 \% \text { ethanolic }\end{array}$ & Aerial parts & Nephrolithiasis & [26] \\
\hline Ethyl acetate fraction & Leaflets & Antioxidant & [26] \\
\hline Hydro-alcoholic & Aerial parts & Antioxidant & {$[36]$} \\
\hline Ethyl-acetate fraction & Aerial parts & Antioxidant & [26] \\
\hline Ethyl-acetate fraction & Leaflets & $\begin{array}{l}\text { Immuno- } \\
\text { modulatory }\end{array}$ & [26] \\
\hline $\begin{array}{c}\text { Ethanolic, butanolic and } \\
\text { methanolic }\end{array}$ & Leaflets & Anti-bacterial & [27] \\
\hline Hydroalcoholic & Entire plant & Anti-bacterial & [26] \\
\hline Aqueous & Entire plant & $\begin{array}{c}\text { Anti- } \\
\text { inflammatory }\end{array}$ & {$[41]$} \\
\hline $50 \%$ ethanolic & Entire plant & $\begin{array}{c}\text { Anti- } \\
\text { inflammatory }\end{array}$ & [39] \\
\hline Chloroform-methanolic & Entire plant & $\begin{array}{c}\text { Anti- } \\
\text { inflammatory }\end{array}$ & {$[42]$} \\
\hline
\end{tabular}

The phytoconstituents present in C. dactylon are usually pharmacologically active, which leads to biological actions responsible for its nutraceutical properties. The corresponding biological action due to its pharmacological nature is listed in Table 4.

\section{Nutraceutical and pharmacological properties of Cynodon dactylon}

C. dactylon, as mentioned earlier, is an excellent source to avail its brilliant nutraceutical properties. Many researchers and scientists have done analytical examinations and experiments with the parts and extracts of $C$. dactylon on animals, as animal sources are easy to be kept, avail, suitable and they also are very adaptable to different environments.

\section{Anti-diabetic activity}

It has been attested numerous times that $C$. dactylon holds hypoglycaemic properties thathelp efficiently handle sugar level in the blood and reduce fatigue. The juice of this plant mixed along with neem juice is very good for the health as it assures to maintain the blood sugar level. ${ }^{[14]}$

The anti-diabetic effect lowered hyperglycaemia, by $70 \%$ ethyl extract of roots and stems of $C$. dactylon. It was found that in diabetes, a joint combination of $10 \mathrm{mg} / \mathrm{kg}$ of xylazine and $60 \mathrm{mg} / \mathrm{kg}$ of ketamine exhibited an anti-diabetic effect. To treat the mice, $50 \mathrm{mg} / \mathrm{kg}$ and $100 \mathrm{mg} / \mathrm{kg}$ of this extract were used and both the administered amount of extracts had a substantial decreasing effect on the blood sugar level. The first dose's impact was seen to be more effective on the mice, as its effect was just like insulin. ${ }^{[15]}$

Moreover, the diabetic rats faced prominent decreased levels of cholesterol, glucose, urea, triglyceride, high-density lipoprotein and low-density lipoprotein due to the effect of non-polysaccharide and aqueous extract of $C$. dactylon. ${ }^{[16]}$

The effect of $250 \mathrm{mg} / \mathrm{kg}, 500 \mathrm{mg} / \mathrm{kg}$ and $1000 \mathrm{mg} / \mathrm{kg}$ of the aqueous extract was examined in the rats having diabetes. The investigation concluded that the dose of $500 \mathrm{mg} / \mathrm{kg}$ given orally was more effective. ${ }^{[17]}$ In normal rats, it lowered sugar level in the blood by $31 \%$, after $4 \mathrm{hr}$ of the administration. ${ }^{[18]}$

Diabetic rats given streptozotocin were treated for the anti-diabetic effect with the ethanolic concoction of root stalks of C. dactylon. The examination disclosed that $500 \mathrm{mg} / \mathrm{kg}$ of the extract, which showed anti-hyperglycaemic activity, was prominently analogous to tolbutamide drug, which is meant to be a standard. ${ }^{[19]}$

\section{Cardiovascular activity}

In a research study, it was found that the rhizome part of $C$. dactylon existed in use to cureheart failure in traditional medicine. It wielded a sturdy protective upshot on heart failure patients, by accompanying positive action of muscle contraction and refining the heart's functions. ${ }^{[20]}$ Further to examine the normal heart contractility and the cardio-related functions, the after-effects of $C$. dactylon's rhizome's hydro-alcoholic excerpts were testified. When administrated to the rats, the extracts headed to insightful improvement in heart functions, which was verified with the help of reduced right ventricular end-diastolic pressure and raised mean arterial pressure. The extract also showed that it helped reduce congestion, of the lung and the heart. ${ }^{[21]}$

The potential haemostatic activity of $C$. dactylon was premeditated in albino rats of both the control and test group. The control group's bleeding time was generally noted to be $160.5 \pm 8.3$ second and the clotting time was marked at $507.6 \pm 18.2$ second. The haemostatic effect of $C$. dactylon in, the test group was observed to be decreasing both the bleeding and clotting time to $96.8 \pm 10.3$ second and $319.3 \pm 27.1$ second, respectively. ${ }^{[22]}$

\section{Anti-arrhythmic activity}

Ischemia is a state where a body tissue in which it abstained from blood flow for a little moment. In contrast, reperfusion is damage caused to the body tissue due to the flow of blood returning to the ischemia region. Ventricular tachycardia is a state of the heart. The lower chambers, the ventricles beat in an increased speed, whereas, ventricular fibrillation is a fatal phenomenon of the heart, where it beats in a hasty speed and can lead to a heart attack. ${ }^{[23]}$

The probability of the anti-arrhythmic effect of extracts of C. dactylon was testified on the isolated heart of rat induced with ischemia and reperfusion. Then the rat hearts were exposed to ischemia and reperfusion regionally for $30 \mathrm{~min}$ respectively with the $C$. dactylon's rhizomes' hydro-alcoholic extracts in the fraction of $25 \mu \mathrm{g} / \mathrm{ml}, 50 \mu \mathrm{g} / \mathrm{ml}, 100 \mu \mathrm{g} / \mathrm{ml}$ and $200 \mu \mathrm{g} / \mathrm{ml}$. The hydro-alcoholic extract yielded insight deduction in the numbers, time period and the incidence of ventricular tachycardia respectively at first two doses; also it lowered the aggregate number of the ventricular beats through ischemia when treated with all the doses respectively except $200 \mu \mathrm{g} / \mathrm{ml}$. Through reperfusion, the frequency of ventricular tachycardia occurrence reduced to $13 \%$ and $33 \%$ from $100 \%$, when treated with the first two doses respectively. Apart from this, it was seen that it reduced the chance of ventricular fibrillation with the same rate at the same given concentrations. ${ }^{[24]}$ 
It was observed that $C$. dactylon also helped in reducing up the bleeding time and clotting time, too, while testing its haemostasis property on albino rats. ${ }^{[22]}$

\section{Anti-microbial activity}

The extract of $C$. dactylon's leaves was used to examine the in vitro antibacterial effects counter to micro-organisms like Streptococcus pyrogenes, Staphylococcus aureus and Escherichia coli. The most effective concentration of the extract was $10 \%$ which worked efficiently as an anti-bacterial concoction. Micro-organisms like Pseudomonas aeruginosa, Staphylococcus aureus, Candida albicans, Escherichia coli, Proteus mirabilis and Klebsiella pneumoniae were taken to evaluate the anti-microbial effects on them with 50 to $400 \mathrm{mg}$ per $\mathrm{ml}$ of $C$. dactylon's aqueous extracts. ${ }^{[25]}$

Two Gram-positive bacteria, namely Staphylococcus aureus and Staphylococcus albus and two gram-negative bacteria, Pseudomonas aeruginosa and Escherichia coli were studied for the anti-microbial effect of its hydro-alcoholic extracts by well agar diffusion and microdilution. It resulted effectively, showing that all the microbial strains were profoundly sensitive to the extract's action. ${ }^{[26]}$

In another study, bioactive compounds in nature in C. dactylon's leaves were tested for its anti-microbial property counter to microbial pathogens like Pseudomonas aeruginosa, Escherichia coli, Bacillus subtilis, Staphylococcus aureus, Streptococcus pyogens, Klebsiella pneumoniae and Proteus mirabillis by a method of the paper disc. The bio-active compounds were extracted using organic solvents of six different types, among which the most effective was the butanolic extract of the leaves and then followed by ethyl ester extract, methanol extract, petroleum ether extract and chloroform extract. ${ }^{[27]}$

\section{Anti-ulcer activity}

In research, to study the anti-ulcer property of C. dactylon, rats were induced to have gastro-intestinal ulcers by feeding them indomethacin. The standard drug, famotidine, was used as a reference to the anti-ulcer effect. To study the anti-ulcer effect, $50 \%$ of $C$. dactylon's ethanolic extract was referred orally in the dosage of $300 \mathrm{mg} / \mathrm{kg}$ and $600 \mathrm{mg} / \mathrm{kg}, 30 \mathrm{~min}$ before feeding them with indomethacin. Both the dosage, $300 \mathrm{mg} / \mathrm{kg}$ and $600 \mathrm{mg} / \mathrm{kg}$, showed a shielding effect on the ulcers, induced by the indomethacin by $54.74 \%{ }^{[28]}$

C. dactylon's gastro-protective activity was examined against gastric mucosa damage, induced by indomethacin and alcohol. They were grouped as indomethacin-induced rat section and alcohol-induced rat section. The reference group, standard group and test group of both the induced sections were administered with ulcerogens, $25 \mathrm{mg} / \mathrm{kg}$ of ranitidine and $300 \mathrm{mg} / \mathrm{kg}$ of juice triturate of C. dactylon respectively, before exposing them to ulcerogens. The rats were then dissected after $4 \mathrm{hr}$ of their ulcerogenic exposure. In the dissection procedure, numerations of how many ulcers were found with their sizes and indexes were penned down. The section of rats induced with alcohol and their antiulcer property was observed most significantly in the test group, given the juice triturate of $C$. dactylon, contrary to the reference and standard group. Though, in the section of rats induced with indomethacin, the standard group pre-treated with ranitidine gave better results. ${ }^{[28]}$

A substantial deduction of ulcer index was also observed against ulcers induced by aspirin and ethanol and pylorus ligation of rats, treating them with the extracts of $C$. dactylon. It also further showed a gastro-protective outcome on examining the stomach of the rats histopathologically. ${ }^{[29]}$

\section{Diuretic activity}

Rats were evaluated for the diuretic activity by $C$. dactylon's aqueous extracts with the dosage of $100 \mathrm{mg} / \mathrm{kg} /$ body weight, $250 \mathrm{mg} / \mathrm{kg} /$ body weight, $500 \mathrm{mg} / \mathrm{kg} /$ body weight and $750 \mathrm{mg} / \mathrm{kg} /$ body weight when given orally. ${ }^{[30]}$

The study unfolded that, treated rats urinated four times more than the normal rats and also the amount of potassium ions, sodium ions and chloride ions excreted were augmented. ${ }^{[31]}$

The diuretic potential possessed by C. dactylon, when examined, showed intense results, stating that the rats given the extracts orally, increased the output of urination and electrolytes excreted in comparison to the rats given standard therapeutic drugs. ${ }^{[30]}$

\section{Pharmacological activity on the central nervous system (CNS)}

Altering of catecholamine levels and the amino acids of the brain in mice were investigated as the result of anti-convulsive nature of the ethanolic extract of aerial parts of $C$. dactylon. It showed the defensive property in contrast to high involuntary muscle contractions or convulsions prompted by some chemo agents in mice. ${ }^{[32]}$

The examination of CNS related activities in mice was attested by the dehydrated aerial extracts of $C$. dactylon. The ethanolic aerial extracts were calculated to examine its related CNS depressants. It also came out to be the root cause of visible disintegration in mice's normal behavioural profile. ${ }^{[33]}$

\section{Dermatological activity}

The potential C. dactylon to heal dermatological wounds categorized in the wound by excision and wound by incision was studied in albino rats. They were treated with the $C$. dactylon gel made by its alcoholic and aqueous extract. It resulted in wound healing in the speedy rate in both wound by excision and incision. ${ }^{[34]}$

The potential of healing of both excision and incision wound was also evaluated in mice, by treating them with the flavonoid concentrate of C. dactylon. The flavonoid concentrate was smeared externally over the wound daily for a week. The protein and collagen escalation in the body with the reduction of the fat peroxides in granulation flesh proved the flavonoid potential helped enhance the process of healing. ${ }^{[35]}$

\section{Antioxidant activity}

The antioxidant of $C$. dactylon evaluated in vitro by several assays like nitric oxide scavenging assay, DPPH radical scavenging activity, superoxide anion radical scavenging assay, ferrous chelating ability, hydrogen peroxide scavenging activity, ABTS assay and hydroxyl radical scavenging assay, by taking a hydro-alcoholic extract of its aerial part. It was observed that the free radicals in a manner of concentrated dependence were scavenged in all the methods as mentioned above performed. Extreme inhibition in superoxide anion radical method was noted to be $93.33 \%$ and the antioxidant ability corresponding to the equal amount of ascorbic acid was noted to be $172.39 \mathrm{mg}$ per gram of the aerial extract. ${ }^{[36]}$

\section{Anti-nephrolithiasis activity}

Aqueous-ethanolic concentrate of $C$. dactylon showed that it could shrink the stones of calcium oxalate present in the rodent kidney by $40 \%$ to $55 \%$ individually. It helped in kidney stone expulsion beneficially and also employed in humans. It was evaluated that the impact of the excerpts of this plant has a protective and therapeutic consequence in tentatively initiated nephrolithiasis. ${ }^{[37]}$

Rats empirically induced with nephrolithiasis were studied for the antinephrolithiasis effect of $C$. dactylon's hydro-alcoholic extract on them. Regular inspection of renal histology, crystalluria, biochemical present in urine and other mutable compounds, was thoroughly carried out. 
Treated rats showed reduced calcium oxalate deposition in papillary and medullary part of the kidneys. ${ }^{[38]}$

\section{Analgesic activity}

$50 \%$ each of $300 \mathrm{mg} / \mathrm{kg}$ and $600 \mathrm{mg} / \mathrm{kg}$ amount of $C$. dactylon's ethanolic extract was made and taken to evaluate the analgesic impact on albino rats against pain, inflammation, oedema (induced with carrageenan), enzymes' activity and the formation of lipid peroxide and granuloma while practising inflammation experimentally. The extract was then administered orally for a week to albino rats. Substantially, it worked significantly in repressing oedema in the paw. It also helped reducing peroxide output, the elevated formation of granuloma and the elevated activity of enzymes during and causing inflammation. To study the analgesic effect of the extract, albino mice were induced muscle contortions with acetic acid. It was later observed that the extract profoundly helped in elevating the threshold of the pain in albino mice. ${ }^{[39]}$

\section{Anti-inflammatory}

To validate the anti-inflammatory effects on rats, compounds like histamine, carrageenan and serotonin dextran were used to induce oedema in the paw. Oedema is a bulging or swelling of a body part due to entrapment of fluids in the body. ${ }^{[40]}$ Fractions of $200 \mathrm{mg} / \mathrm{kg}, 400 \mathrm{mg} / \mathrm{kg}$ and $600 \mathrm{mg} / \mathrm{kg}$ per bodyweight of the rats, C. dactylon's aqueous extract, were taken to treat oedema. All the requisite trials showed substantial activity $C$. dactylon towards anti-inflammation. ${ }^{[41]}$

In another study, $125 \mathrm{mg} / \mathrm{kg}, 250 \mathrm{mg} / \mathrm{kg}$ and $500 \mathrm{mg} / \mathrm{kg} \mathrm{C}$. dactylon's chloroform-methanolic extract taken to treat carrageenan-induced acute and chronic oedema in the rat paw, also to analyse its natural anti-inflammatory effect with comparison to standard indomethacin anti-inflammatory drug. ${ }^{[42]}$

\section{Anti-pyretic activity}

The anti-pyretic effect was examined using a different dosage of C. dactylon's aqueous extract, against contortions or pain caused by acetic acid and hot plate and hyperthermia caused by the yeast, in mice. It was observed that the extract showed both the activities in a substantial way. Also, the aqueous extract bared antipyretic effect in reducing the temperature in the rectum of mice, when treated with the dosage of $600 \mathrm{mg} / \mathrm{kg}$ of the extract. ${ }^{[43]}$

\section{Anti-diarrhoeal activity}

Hexane, ethyl acetate and dichloromethane with the methanol concoction of $C$. dactylon plant in the examination were verified in albino rats aimed at anti-diarrhoeal activity castor oil tempted diarrhoea. Methanolic extricate displayed an impressive decrease in the hindrance of castor oil tempted diarrhoea and indicated a critical lessening in gastrointestinal motility. These outcomes demonstrate that this plant has great antidiarrheal property. ${ }^{[44]}$

\section{Antiviral activity}

In vivo testing, black tiger shrimps were administered $1 \%$ to $2 \%$ extracts of C. dactylon orally in large quantity which displayed strong antiviral action in contrast to white spot syndrome virus and they have likewise been accounted for to have a high antiviral effect against white spot syndrome virus with zero mortality. ${ }^{[45]}$

\section{Future Scope}

C. dactylon is a nutraceutically rich entity which has the potential to excel in the field of medicine. Its medicinal properties can flourish with the advent of Nano-encapsulation technology, where Nano-sized particles of whether gas, liquid or solid are entrapped within a subordinate matter to form a packed nanocapsule. As the technology of Nano-encapsulation is merited for its advantages like target, triggered and sustained release, the phytoconstituents of $C$. dactylon, which are biologically active, can be nano-encapsulated for the better healing process of ailments.

On another view, it can be juiced and mixed with other medicinal concoctions and can be consumed as an herbal drink.

\section{CONCLUSION}

This review discusses primarily the nutraceutical and pharmacological potential possessed by Cynodon dactylon. Its various nutracurative and pharmacological properties excelled by phytoconstituents' presence substantially helps to cure infections and diseases. This has greatly attracted scientists and researchers to revolve their experiments around investigating and evaluating the resulting output of its curative action on various ailments. On animal experimentation, it has shown maximum positive results as an herbal curative. Its eye-widening healing properties to treat ailments like nephrolithiasis, inflammation, diabetes, fungal/microbial infections, diarrhoea etc. Inspire young scientists and researchers to further explore its hidden properties and to inculcate them in wider pharmacological use in the fields of science and medicine.

\section{ACKNOWLEDGEMENT}

Authors are highly obliged to Lovely Professional University for their moral support to bring this manuscript in its final form.

\section{CONFLICT OF INTEREST}

There is no conflict of interest.

\section{Financial support and sponsorship}

No financial support has been taken for the preparation of this manuscript.

\section{ABBREVIATIONS}

C. dactylon: Cynodon dactylon; CNS: Central Nervous System; DPPH: 2,2-diphenyl-1-picrylhydrazyl; ABTS: 2,2'-azino-bis(3-ethylbenzothiazoline-6-sulfonate).

\section{REFERENCES}

1. Al-Snafi AE. Chemical constituents and pharmacological effects of Lathyrus sativus: A review. IOSR Journal of Pharmacy. 2019;9(6):51-8.

2. Horowitz M. Bermudagrass (Cynodon dactylon): A history of the weed and its control in Israel. Phytoparasitica. 1996;24(4):305-20.

3. Avitzur S. Changes in Agriculture of Eretz-Israel 1875-1975. Milo, Tel Aviv, Israel (in Hebrew). 1977.

4. Hameed M, Ashraf M. Physiological and biochemical adaptations of Cynodon dactylon (L.) Pers. from the Salt Range (Pakistan) to salinity stress. Flora-Morphology, Distribution, Functional Ecology of Plants. 2008;203(8):683-94.

5. Taliaferro CM. Diversity and vulnerability of Bermuda turf grass species. Crop Science. 1995;35(2):327-32

6. Harlan JR, Wet DJM. Sources of variation in Cynodon dactylon (L). Pers. 1. Crop Science. 1969; 9(6):774-8.

7. Dong M, Kroon DH. Plasticity in morphology and biomass allocation in Cynodon dactylon, a grass species forming stolons and rhizomes. Oikos. 1994;99-106.

8. Jianxiu L, Aigui G, Hailin G. Morphological variation and types of Cynodon dactylon. Acta Prataculturae Sinica. 2003;12(6):99-104.

9. Shabi MM, Gayathri K, Venkatalakshmi R, Sasikala C. Chemical constituents of hydro alcoholic extract and phenolic fraction of Cynodon dactylon. Int J Chem Tech Res. 2010;2(1):149-54.

10. Suresh K. Antimicrobial and Phytochemical Investigation of the Leaves of Carica papaya L., Cynodon dactylon (L.) Pers., Euphorbia hirta L., Melia azedarach L. and Psidiumguajava L. Ethnobotanical Leaflets. 2008;2008(1):157.

11. Shabi MM, Raj CD, Sasikala C, Gayathri K, Joseph J. Negative inotropic and chronotropic effects of phenolic fraction from Cynodon dactylon (Linn) on isolated perfused frog heart. Journal of Scientific Research. 2012;4(3):657-63

12. Sadki C, Hacht B, Souliman A, Atmani F. Acute diuretic activity of aqueous Erica 
multiflora flowers and Cynodon dactylon rhizomes extracts in rats. Journal of Ethnopharmacology. 2010;128(2):352-6.

13. Solanki R, Nagori BP. Screening of antibacterial activity of hydroalcoholic extract of Cynodon dactylon. International Journal of Research in Ayurveda and Pharmacy. 2012;3(5)

14. HeWM, Alpert P, Yu FH, Zhang LL, Dong M. Reciprocal and coincident patchiness of multiple resources differentially affect benefits of clonal integration in two perennial plants. Journal of Ecology. 2011;99(5):1202-10.

15. Nafisi S, Nezhady MA, Asghari MH. Comparative and mixture effect of Cynodon dactylon, electromagnetic field and insulin on diabetic mouse. Balkan Medical Journal. 2012;29(4):345

16. Jarald $E E$, Joshi $S B$, Jain DC. Antidiabetic activity of aqueous extract and non-polysaccharide fraction of Cynodon dactylon Pers. IJEB. 2008;46:660-7.

17. Rai PK, Jaiswal D, Rai DK, Sharma B, Watal G. Antioxidant potential of oral feeding of Cynodon dactylon extract on diabetes-induced oxidative stress. Journal of Food Biochemistry. 2010 Feb;34(1):78-92.

18. Singh SK, Kesari AN, Gupta RK, Jaiswal D, Watal G. Assessment of antidiabetic potential of Cynodon dactylon extract in streptozotocin diabetic rats. Journal of Ethnopharmacology. 2007;114(2):174-9.

19. Kumar AS, Gnananath K, Kiran D, Reddy AM, Ch R. Antidiabetic activity of ethanolic extract of Cynodon dactylon root stalks in streptozotocin induced diabetic rats. Int J Adv Pharm Res. 2011;2(8):418-22.

20. Bagewadi ZK, Siddanagouda RS, Baligar PG. Phytoconstituents investigation by LC-MS and evaluation of anti-microbial and anti-pyretic properties of Cynodon dactylon. International Journal of Pharmaceutical Sciences and Research. 2014 5(7):2874.

21. Garjani A, Afrooziyan A, Nazemiyeh H, Najafi M, Kharazmkia A, Maleki-Dizaji N. Protective effects of hydroalcoholic extract from rhizomes of Cynodon dactylon (L.) Pers. on compensated right heart failure in rats. BMC Complementary and Alternative Medicine. 2009;9(1):1-9.

22. Hugar L, Ramesh H. Evaluation of haemostatic effect of Cynodon dactylon pers in albino rats. Journal of Evolution of Medical and Dental Sciences. 2014 Mar 17;3(11):2711-4.

23. Luca MC. Assessment of Endothelial Function and Approaches to Prevent Ischemia and Reperfusion-Induced Endothelial Dysfunction in Humans. University of Toronto Canada. 2012.

24. Najafi M, Ghavimi H, Gharakhani A, Garjani A. Effects of hydroalcoholic extract of Cynodon dactylon (L.) pers. on ischemia/reperfusion-induced arrhythmias. DARU Journal of Pharmaceutical Sciences. 2015;16(4):233-8.

25. Pranita K, Hemant SA, Koushlesh MK. Antibacterial evaluation of ethanolic extract of Cynodon dactylon (I.) Pers. Global Journal of Research on Medicinal Plants and Indigenous Medicine. 2012;1(6):218.

26. Ashokkumar K, Selvaraj K, Muthukrishnan SD. Cynodon dactylon (L.) Pers.: An updated review of its phytochemistry and pharmacology. Journal of Medicinal Plants Research. 2013;7(48):3477-83.

27. Chaudhari Y, Mody HR, Acharya VB. Antibacterial activity of Cynodon dactylon on different bacterial pathogens isolated from clinical samples. International Journal of Pharmaceutical Studies and Research. 2011;1:16-20.
28. Ramesh H. Preclinical evaluation of protective effect of Cynodon dactylon pers on experimentally induced gastric mucosal damage. Journal of Medical and Health Sciences. 2013;2(3):89-93.

29. Babu KS, Shaker IA, Kumaraswamy D, Saleembasha S, Sailaja I. Indigenous effect of Cynodon dactylon in experimental induced ulcers and gastric secretions. Int Res J Pharm. 2012;3(5):301-4.

30. Aruna D, Chakarvarthy K, Sarath BK. Diuretic efficacy of Cynodon dactylon on guinea pigs with comparison of medium efficacy. Int. J Bioassay. 2013;2(3):500-2.

31. KP SG, Satish S, Mahesh CM. Study on the diuretic activity of Cynodon dactylon root stalk extract in albino rats. Evaluation. 2009;7:11.

32. Pal DK. Determination of brain biogenic amines in Cynodon dactylon Pers. and Cyperus rotundus L. treated mice. Int J Pharm Pharm Sci. 2009;1(1):190-7.

33. Pal D. Evaluation of CNS activities of aerial parts of Cynodon dactylon Pers. in mice. Acta Pol Pharm. 2008;65(1):37-43

34. Dande PA, Khan AN. Evaluation of wound healing potential of Cynodon dactylon. Asian J Pharm Clin Res. 2012;5(3):161-4

35. Saroja M, Santhi R, Annapoorani S. Wound healing activity of flavonoid fraction of Cynodon dactylon in Swiss albino mice. International Research Journal of Pharmacy. 2012;3(2):230-1.

36. Jananie RK, Priya V, Vijayalakshmi K. In vitro assessment of free radical scavenging activity of Cynodon dactylon. J. Chem. Pharm. Res. 2011;3(4):647-54.

37. Albert-Baskar A, Ignacimuthu S. Chemopreventive effect of Cynodon dactylon (L.) Pers. extract against DMH-induced colon carcinogenesis in experimental animals. Experimental and Toxicologic Pathology. 2010;62(4):423-31.

38. Rad KA, Hajzadeh MA, Rajaei Z, Sadeghian MH, Hashemi N, Keshavarzi Z. Preventive effect of Cynodon dactylon against ethylene glycol-induced nephrolithiasis in male rats. Avicenna Journal of Phytomedicine. 2011;1(1):14-23.

39. Dhande SR. Anti-inflammatory and analgesic properties of the $50 \%$ ethanolic extract of Cynodon dactylon Pers. International Research Journal for Inventions in Pharmaceutical Sciences. 2013;1 (2):8-16.

40. Sindhu G, Ratheesh M, Shyni GL, Helen A. Inhibitory effects of Cynodon dactylon $\mathrm{L}$. on inflammation and oxidative stress in adjuvant treated rats. Immunopharmacology and Immunotoxicology. 2009;31(4):647-53.

41. Garg VK, Paliwal SK. Anti-inflammatory activity of aqueous extract of Cynodon dactylon. International Journal of Pharmacology. 2011;7(3):370-5.

42. Yogesh HS, Kichadi SC, Muchandi IS, Gopalakrishna B. Evaluation of Anti-Inflammatory activity of Cynodon dactylon Pers. On carrageenan induced paw edema in rats. Indian Journal of Natural Products and Resources. 2013:4(2):151-4

43. Garg VK, Khosa RL. Analgesic and anti-pyretic activity of aqueous extract of Cynodon dactylon. Pharmacologyonline. 2008;3:12-8.

44. Babu DR, Neeharika V, Pallavi V, Reddy MB. Antidiarrheal activity of Cynodon dactylon. pers. Pharmacognosy Magazine. 2009;5(19):23.

45. Balasubramanian G, Sarathi M, Venkatesan C, Thomas J, Hameed AS. Oral administration of antiviral plant extract of Cynodon dactylon on a large scale production against white spot syndrome virus (WSSV) in Penaeus monodon. Aquaculture. 2008;279(1-4):2-5.

\section{GRAPHICAL ABSTRACT}

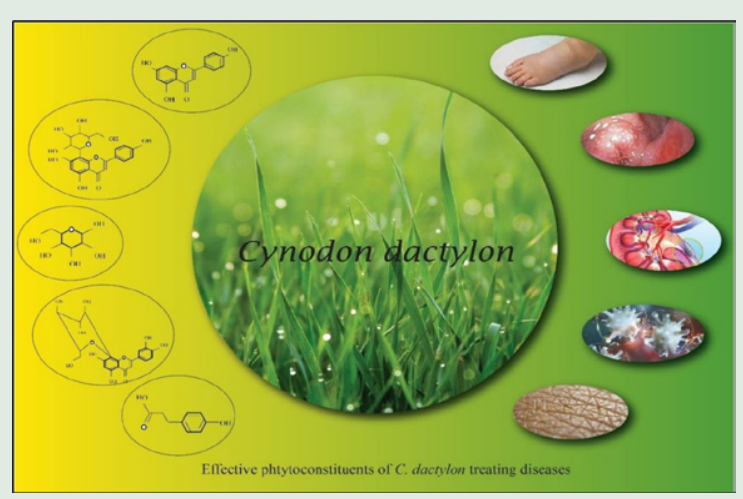

\section{SUMMARY}

Cynodon dactylon is a perennial grass weed, which has its roots in folklore medicines. It has various pharmacological and nutraceutical properties due to the presence of phytochemicals like Ethyl acetate, Levoglucosenone, Hydroquinone, Furfural, Apigenin etc. Having several "anti" properties, these phytochemicals are effective against several ailments like edema, inflammation, nephrolithiasis, psoriasis, bacterial infection etc. This review on C. dactylon, mentioning about its diverse pharmacological and nutraceutical properties would be valuable to the researchers and scientists to explore more about its diversity in medicine. 


\section{ABOUT AUTHORS}

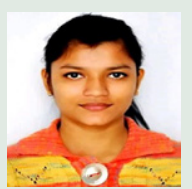

Ms. Shweta Das is a student in Lovely Professional University, Punjab, pursuing M.Sc. in Food Science and Technology. She did her graduation from Uttaranchal University, Dehradun, in B.Sc. Honours Food Technology. She has keen interest towards nutraceutical properties of plant based food and intend to research upon it to raise awareness for public and mental health.

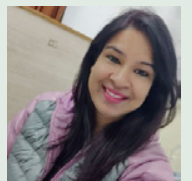

Dr. Sonia Morya has specialization in Food Science \& Technology. Her research interests include probiotic beverages, herbal wines, nutraceutical, gluten free products, new product development etc. Currently she holds the post as an assistant professor at Lovely Professional University, India. She has published around 30 research articles along with chapters.

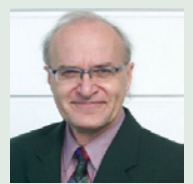

Mr. Arno Neumann completed a BSc. in Microbiology from the University of British Columbia, Canada. He pursued various graduate courses in Medical Microbiology and worked in technical research. Is continuing with applied biotechnology in business as co-founder of BET Bioscience Extraction Technologies Inc .

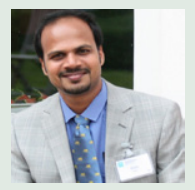

Dr. Vijay Kumar Chattu is a medical doctor specialized with MD in Community Medicine and holds an MPH from Belgium. His research interests include health promotion, public health nutrition and mental health. Currently he holds Research affiliations with University of Toronto, Canada and at Global Institute of Public Health, India. He has published over 200 research articles on various public health topics in top tier journals.

Cite this article: Das S, Morya S, Neumann A, Chattu VK. A Review of the Pharmacological and Nutraceutical Properties of Cynodon dactylon. Pharmacog Res. 2021;13(3):104-12. 